\title{
読書における文字の大きさ，配列および 色彩による疲労について
}

\author{
東京㴹科火学生理学教室（主任 伊藤秀三郎教授） \\ 佐 \\ 藤 \\ 栄 \\ Sakae Sato
}

和洋女子大学生理学教室（主任川村一男助教授）

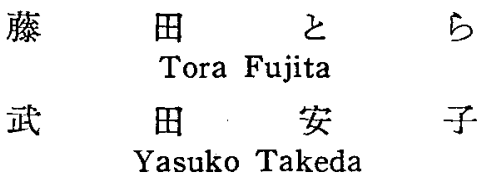

\section{I 緒 言}

從来交字の大きさ並びに，配列即ら縦書き，横書き については，その可読時間を記録し媵労其の他を取报 つた心理学的研究はあるが，これを生理学的方面より 研究を進めたものは少ない。

そこで著者等梳交字の大きさ, 配列即ち縦書き, 横

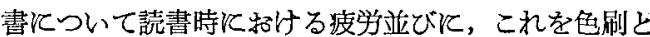
した場合の疲労に対する影響等について研究したとこ ろ，いささか知見を得たのでここに報告する。

\section{II 実験方法}

（1）被験者 被験者としては，和洋女子大学(19～ 22才）の中で，両眼健全で裸眼視力 1.0 以上の者 5 名 を選んだ。

（2）疲学判定方法疲学の程度を判定するには,

Flicker TEST によつて行つた。

被験者を約 10 分間同し環境のめのに休息せしめた のち読青前の「フリッカー」値(以下 F值と略称する) を「フリッカー」計で測定し，これを被験者夫々の対 照值として, 其の後 30 分間有意文字を音読せしめ, 読書後直らに F 值を求め，これより同様の環境の下に 30 分閪休息せしめて，休息後更飞F值を測定した。こ の方法によつて得た二つのF值は夫々の対照值に対す る百分率で取扱つた。

（3）読蓄材料 中学校 3 年の国語教科書より採用し 四節よりなる有意文字で，字数は 3450 字である。活
字の大きさは 2 号活字と 6 号活字を用い，これる緃書 きと横畫きとし, 更に黒, 赤, 青及び緑の四種類の色 刷とした。

（6）光源 光源は，普通電灯下で行い，明度は 100 ルックスとした。

\section{III 実験結果並ひに考察}

1,2 号活宇縦書（黒）を読書した場合の結果を示す と第 I表のようである。

第 I表 2 号活字綐書の場合

第 I表汇

\begin{tabular}{|c|c|c|}
\hline 例 数 & 30分読書直後 & 30分休息後 \\
\hline 1 & $95.2 \%$ & $98.9 \%$ \\
2 & 95.2 & 100.0 \\
3 & 96.5 & 98.8 \\
4 & 96.5 & 99.5 \\
5 & 97.5 & 101.4 \\
\hline 平 均 & $96.2 \pm 0.9$ & $99.7 \pm 0.9$ \\
\hline
\end{tabular}

示される とおり, 縦書の場 合は読書 直後では 刘照 100 \%に対乙 F. 値は 対照 $100 \%$ 95.2 97. $5 \%$ であり,平均 96.2 土0.9 となりF值の減少即ち疲 学が垫められる。

佾読書直後 30 分間休息せしめた後のF值を測定し た結果は 98.9〜101.4\%となり，平均 $99.7 \pm 0.9 \%$ で， F值は対照に近ずき，疲学の恢復して行く傾向がうか がわれる。

2. 2 号活字横書 (黒) を読書した場合の結果を示 
すと第II表のようである。

第II表 2 号活字橫青の場合

\begin{tabular}{|c|c|c|}
\hline 例 数 & 30 分読書直後 & 30分休息後 \\
\hline 1 & $97.8 \%$ & 98.99 \\
2 & 97.8 & 102.2 \\
3 & 98.9 & 100.0 \\
4 & 99.5 & 100.0 \\
5 & 100.0 & 100.0 \\
\hline 泣·均 & $98.8 \pm 0.9$ & $100.0 \pm 1.0$ \\
\hline
\end{tabular}

刘照 $100 \%$

第 $\mathrm{V}$ 表 6 号活字横書の場合

第【表汇

示すよう

K, F值

は, 97.8

$\sim 100.0$

\% で平均

$98.8 \pm 0$.

$9 \%$ で,

F値の減

少が認め

られた。また読書30分間休息直後のF值は98.9 102.

$2 \%$ で, 平均 $100.0 \pm 1.0 \%$ で完全に恢復することを 認めた。

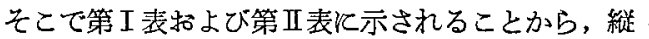
書の場合の平均 $\mathbf{F}$ 値が $96.2 \pm 0.9 \%$ であるに対し,横 专の場合の平均 $\mathrm{F}$ 值は $98.8 \pm 0.9 \%$ て横書の場合の方 が疲学が少ないととが認められた。また恢復度子綖書 が99.7+0.9\%であるのに対し，横書きは $100 \% \pm 1.0 \%$ で，完全恢復することを認めた。

3,6 号活字緥書（黒）を読書した場合の結果を示す と第III表のようである。

第亚表・6 号活字綐菁の場合

\begin{tabular}{|c|c|c|}
\hline 例 数 & 30 分䛨書直後 & 30分休息後 \\
\hline 1 & $93.3 \%$ & $100.5 \%$ \\
2 & 93.4 & 101.1 \\
3 & 95.3 & 101.1 \\
4 & 95.9 & 104.4 \\
5 & 95.9 & 101.1 \\
\hline 平 均 & $94.8 \pm 1.2$ & $100.9 \pm 0.9$ \\
\hline
\end{tabular}

対照 $100 \%$
第亚表江 示すよろ K, 綐書 の場合の 読書直後 のF值は 93.3 95. 9\%, 平均 $\mathrm{F}$ 值 $94.8 \pm 1$.

$2 \%$ 飞減少し，2号活字の縦書飞比しその疲学度が多 いことが認められる。委た 30 分休息後のF值 100.4 〜 $101.1 \%$ となり, 平均 $100.9 \pm 0.9 \%$ となり完全に 恢復していることを示している。

4,6 号活字横書 (黒) を読書した場合の結果を示す と第N表のようである。

第W表汇示すようK，横書の場合の読書直後の $\mathrm{F}$ 值 は 95.2 99.6\% となり,平均 $\mathrm{F}$ 值は $98.2 \pm 1.5 \%$ で あり，対照汶し $\mathrm{F}$ 値の減少が少ない。

休息後のF值は $97.2 \sim 100 \%$ であり，平均 $94.1 \pm$ $1.2 \%$ で疲労恢復も完全に近い。第正表捛よび第IV表 に示すように，緃書の場合の疲学度は横書に比し大き

\begin{tabular}{|c|c|c|}
\hline 例 数 & 30分読書直後 & 30分休息後 \\
\hline 1 & $95.2 \%$ & $97.2 \%$ \\
2 & 97.8 & 98.1 \\
3 & 98.9 & 100.0 \\
4 & 99.6 & 100.0 \\
5 & 99.6 & 100.0 \\
\hline 平 均 & $98.2 \pm 1.5$ & $99.1 \pm 1.2$ \\
\hline
\end{tabular}

$<, 30$ 分

休息後の 疲労饭復 度は大差 がなが た。 かく て活字の 大きさ拉 対照 $100 \%$ 上び配列

による読書時の疲労について次のような結果が得られ た。即ち 2 号活字と 6 号活字の綐書について見ると， 6 号活字の場合の $\mathrm{F}$ 值が1.4\%低く，2号活字上りも疲 労度が大であることが喼められた。

次に横書については, 2 号活字の場合飞括いては98. $8 \pm 0.9 \%$ であり，6 号活字の場合では $98.2 \pm 1.5 \%$ で あまり大きな差は認められなかつた。

色刷による $\mathrm{F}$ 值の変動てついて実験した結果は次の ようである。

活字の大きさによる疲労については，2号活字の方 が 6 号活字よりる疲労が少ないので，2号活字を用い て色刷飞よる $\mathrm{F}$ 值の変動を調べた。

5,2 号活字綐書 (赤) を葹書した場合の結果を示す と第 $\mathrm{V}$ 表のようである。

第 $\mathrm{V}$ 表 2 号活字縦書の赤刷の場合

\begin{tabular}{|c|c|c|}
\hline 例 数 & 30分読書直後 & 30分休息後 \\
\hline 1 & $92.2 \%$ & $98.2 \%$ \\
2 & 94.0 & 97.8 \\
3 & 95.2 & 98.8 \\
4 & 95.8 & 100.0 \\
5 & 97.0 & 98.8 \\
\hline 平 & $94.8 \pm 1.6$ & $98.7 \pm 0.7$ \\
\hline
\end{tabular}

対照 $100 \%$
第V表に 示すよう K, 読書 直後 92 . $2 \sim 97.0$ $\%$ で, 平 均 $94.8 \pm$ $1.6 \%$ で 刘照汶対 ᄂ, $5.2 \%$

のF值を来し，疲学の大きいことが認められた。30分 休息後の状態を見るに，97.8〜100\%で，平均 98.7士 $0.7 \%$ であつて，疲労度が大きく，30分では恢復しな からた。

6,2 号活字横書 (赤) を読書した場合の結果を示す と第U表のようである。

第V表に示すように，93.5 96.9\% で,平均 $\mathrm{F}$ 値は $95.2 \pm 1.2 \%$ となり，30 分間休息後は 96.0 100.0\% となり，平均 $\mathrm{F}$ 值は $97.7 \pm 1.1 \%$ となり 30 分では疲 労は恢復しない。 
第U表 2 㕺活字横畫赤刷の場合

\begin{tabular}{|c|c|c|}
\hline 例 数 & 30分読書直後 & 30分休息後 \\
\hline 1 & ' $93.5 \%$ & 98.206 \\
\hline 2 & 94.2 & 96.0 \\
\hline 3 & 95.2 & 96.7 \\
\hline 4 & 96.3 & 100.0 \\
\hline 5 & 96.9 & 96.7 \\
\hline 平均 & $95.2 \pm 1.2$ & $97.7 \pm 1.1$ \\
\hline
\end{tabular}

対照 $100 \%$

第VI美 2 号活字䋛書緑刷の場合

\begin{tabular}{|c|c|c|}
\hline 例 数 & 30分読書直後 & 30分休息後 \\
\hline 1 & $96.5 \%$ & $100.0 \%$ \\
2 & 96.5 & 101.1 \\
3 & 97.0 & 100.0 \\
4 & 97.5 & 99.2 \\
5 & 99.4 & 101.8 \\
\hline 平 均 & $97.4 \pm 1.1$ & $100.4 \pm 0.9$ \\
\hline
\end{tabular}

対照 $100 \%$
7,2 㝍 活字綎書

(緑) を 読書した 場合の結 果を示す と第VII表 のようで ある。

第VI表 に示すよ ろに, 30 分読書直 後のF值 は, 96.5 $\sim 99.4 \%$ となり， 平均 F 值 $97.4 \pm 1$. 1 吕であ り,疲労が少なく,休息後の恢復は 99.2〜101.8\% で， 平均 $100.4 \pm 0.9 \%$ となり完全なる疲学恢復が虫めら れ，緑出刷の昜合は読書時の疲䇰が最む少ないことが 瑟められた。

8,2 号活字横書 (緑) を読書した場合の結果を示す と第证表のようである。
第W表 2 号活字横書緑刷の場合

\begin{tabular}{|c|c|c|}
\hline 例 数 & 30 分読書直後 & 30分休息後 \\
\hline 1 & $97.8 \%$ & $100.0 \%$ \\
2 & 98.2 & 99.4 \\
3 & 98.9 & 100.0 \\
4 & 100.0 & 100.0 \\
5 & 100.0 & 100.0 \\
\hline 平 均 & $99.0 \pm 0.9$ & $99.9 \pm 0.5$ \\
\hline
\end{tabular}

対照 $100 \%$
第㚼表に

示すよう 読書直後 ○ F 值は $97.8 \sim 10$ $0.0 \%$ と なり, 平 均 $\mathrm{F}$ 值柱 $99.0 \pm 0$. K, 30 分

9 となり，F值の減少が極めて少なく，疲労が最も少 なからた。また 30 分休息後の恢復もほとんど完全に 近い。即ら 2 号活字横書にして緑出の印刷が, 最も F 値の変動が少なく，疲労の少ないことが立証された。

9,2 号活字縦書 (青) を読書した場合の結果を示す と第IX表のようである。

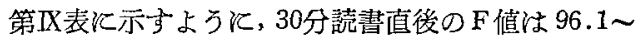
〜99.4\%となり, 平均 F值は $97.4 \pm 1.196$ となり,
第IX表 号活字縋書青刷の埸合

休息後の

\begin{tabular}{|c|c|c|}
\hline 例 数 & 30分読書直後 & 30分休息後 \\
\hline 1 & $96.1 \%$ & $99.5 \%$ \\
2 & 96.8 & 98.2 \\
3 & 97.0 & 98.1 \\
4 & 97.5 & 100.0 \\
5 & 99.4 & 99.5 \\
\hline 平 均 & $97.4 \pm 1: 1$ & $99.1 \pm 0.7$ \\
\hline
\end{tabular}

対照 10096

$\mathrm{F}$ 値 は

$98.1 \sim 10$

$0.0 \% \tau$

あり, 平

均99.1土

$0.7 \%$ て あつた。

10,2号 活字横書

（青）を読書した場合の結果を示すと第X表のようて ある。

第X表 2 号活字啮書青刷の場合

第X表に

\begin{tabular}{|c|c|c|}
\hline 例 数 & 30分読書直後 & 30分休息後 \\
\hline 1 & $95.5 \%$ & $97.8 \%$ \\
2 & 96.4 & 96.4 \\
3 & 97.2 & 100.0 \\
4 & 99.6 & 104.0 \\
5 & 100.0 & 101.2 \\
\hline 平 均 & $97.7 \pm 1.8$ & $99.9 \pm 2.6$ \\
\hline
\end{tabular}

示すよう

K. 30分

読書直後

のF值は

95.5 10

$0.0 \%$ で

平均 97.7

$\pm 1.8 \%$

対照 100\%

であっ

た。休息後のF值は 96.4〜104.0\% で平均 99.9 土 $2.6 \%$ であつた。

\section{IV 結 諭}

和洋女子大学生 5 人を被験者として, 読書時に和け る文字の大きさ，配列，色彩化よるF值の変動即ち疲 学状態を調べたところ次のような結果を得た。

1) 交字の大きさでは，6号活字よりる，2号活字 の方がF值の減少即ら波学す少なく，30分休息後に括 ける恢復状態す良好であつた。

2) 同じ太きさの活字の場合は縦書よりる横書の方 がF值の減少即ち疲学が少なかつた。

3）色彩火よるF值の変動は, 黒, 緑, 青刷の場合 に，緑刷の方が，わずかながら疲労が少なく，また瘦 労恢復子早かつた。

4）赤刷の場合に F 值の減少が大で, 疲労し易く, 30分の休息で正疲労は恢復しない。

終りに本実験にあたり御愍篤なる御指導と御校閲を 賜つた伊藤秀三郎教授に感謝の意を表するとともに， 御便宣を戴き御指導をいただいた和洋女子大学生理学 教室川村一男助教授に謝意を表する次第である。

$$
\text { 文、献 }
$$

1）草島時介（1956）読書の科学—その心理と生 
$-78-(868)$

理 明治図書出版株式会社 東京

2) 林修 (1954) 眼科から見た縦書，横畫の間題 眼科臨床医報 48,65

3）坪田草子（1953）作業能率と眼の機能に関する
研究・日本眼科学会杂隹誌 59 (1239)

4) 藤田とら (1956) 和裁连針飞関する医学的研究 （第I報）和洋女子大学紀要・第一䡣

\title{
東京都内における散娼の居住状況と淋疾 䍜患率に関する研究
}

\author{
東京都衛生局予防部（部長 高㗚末雄） \\ 細田弘 \\ Hirosi Hosoda \\ 日本医科大学衛生学教空 (主任 八田貞義教授) \\ 岸 \\ Atusi Kisi \\ 城石 豊 \\ Yutaka Siroisi \\ 野村宽 \\ Hiroshi Nomura
}

I.まえがき

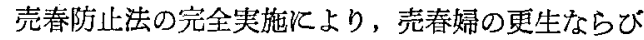
飞性病感染源の一掃が大い期待されるが，我が国の 現状に㨟いて直ちにこれを望むことは真に困難なこと と言わね法なるまい。即ち赤線業者等の疑装転業, 更 飞集娼の集団的散㛎化等々，売春防止法の全面施行を 妨げると思われる諸現象の続発が考学られ，斯かる場 合の衛生管理の不徹底から逆忆性病㭧者の急增するこ とも予想されるのである。

先に山口等 ${ }^{11}$ は集娼の散娼化といろ問題を取り上 げ，集娼・散娼両群沉けるる淋疾羅㭧率を培養法を用 いて比較し，散娼に执ける淋疾躍患率の高いのはその 衛生管理の不徹底汇よるものであるうと指摘した。

著者等はこの散娼の生態, 殊飞その居住状況につい て調査し，これと淋疾羅患率との関係について併せ検 討を行つた。

\section{II. 調查 方 法}

昭和 31 年 1 月より 10 月迄の間澢都内各警察署保 挙留置された売春容疑婦 3,255 名中, 集娼（都内赤線 或々青線業態婦）之判断されるものを除外して, 散娼 2,957 名《ついて調查を行つた。

即ち, これらの散娼の氏名, 年令, 住所, 検挙され
た警祭署等を根拋として，同一人と思考し得るものを 判定し, 検挙回数, 居住状況, 地区別分布状況, 更江 これらと淋菌検出率（子宮頸管及び尿道口よりの）上 の関倸について検討を加兄た。

\section{III. 調 查 成 績}

（1）検挙回数之淋菌検出率（第 1 表）

ここで特異な点は, 検挙回数の多いものほぞ淋菌検 出率が低いととである。換言すば売㸒の常習著しいも

符 1 表 散娼の検挙回数と淋菌検出率

\begin{tabular}{|c|c|c|c|c|}
\hline 検挙回数 & 検 挙 者 & 検挙延数 & 淋菌検出 & 淋菌検出率 \\
\hline 1 回 & 1788 & 1788 & 208 & 11.6 \\
\hline $2 \prime$ & 345 & 690 & 70 & 10.1 \\
\hline $3 "$ & 83 & 249 & 20 & 8.0 \\
\hline 411 & 29 & 116 & 10 & 8.6 \\
\hline $5 \prime$ & .12 & 60 & 3 & \\
\hline $6 "$ & 5 & 30 & 3 & \\
\hline $7 "$ & 1 & 7 & 0 & 6.1 \\
\hline $8 "$ & 1 & 8 & 1 & \\
\hline 91 & 1 & 9 & 0 & \\
\hline 計 & 2265名 & 2957名 & 315例 & $10.6 \%$ \\
\hline
\end{tabular}

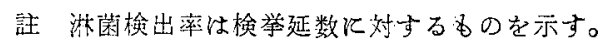

